\title{
ワカメ無機成分 $(\mathrm{Fe}, \mathrm{Ca}, \mathrm{I}, \mathrm{P}, \mathrm{Mg})$ の人工消化液による 溶出について
}

\author{
伊 藤 里 美, 三 好保 \\ 藤 井 正信, 今 木 雅 英 \\ 徳島大学医学部公衆衛生学教室
}

\author{
Exudation of Minerals ( $\mathrm{Fe}, \mathrm{Ca}, \mathrm{I}, \mathrm{P}, \mathrm{Mg}$ ) from the Seaweed \\ "Wakame" (Undaria pinnatifida) during Artificial \\ Digestion by Fluid-Immersion Treatment
}

\author{
Satomi ITO, Tamotsu MIYOSHI, Masanobu FUJII and Masahide IMAKI \\ Department of Public Health, School of Medicine, The University of Tokushima, \\ Tokushima 770
}

\begin{abstract}
Nippon Eiyō Shokuryō Gakkaishi (J. Jpn. Soc. Nutr. Food Sci.) 41, 293 298 (1988)
The contents of general nutrients in dried "naruto wakame" (Undaria pinnatifida) were investigated and the results obtained were as follows; Crude ash : 16-44\%, Protein : 7.5-24.2\%, Lipid : 1.4-6.8\%, Carbohydrate $: 37-49 \%$. The contents of minerals in dried "naruto wakame" were spread over the following ranges : $\mathrm{Fe}: 6.3-30 \mathrm{mg} \%, \mathrm{Ca}: 647-1,176 \mathrm{mg} \%, \mathrm{I}: 95-157 \mathrm{ppm}, \mathrm{P}: 237-425 \mathrm{mg} \%, \mathrm{Mg}: 163-312 \mathrm{mg} \%$, although they varied with the size and part of the sample. Of the total I in dried "naruto wakame", 28-31\% was extracted in the first step with warm distilled water, 11-12\% in the second step with ethanol, none by treatment with benzene, and $57-59 \%$ of the total remained in the residue. The extraction rates of minerals from "naruto wakame" during immersion treatment with artificial digestion fluid for $30-120 \mathrm{~min}$ at $37^{\circ} \mathrm{C}$ were approximately as follows; Crude ash: $85 \pm 10 \%, \mathrm{Fe}: 45 \pm 29 \%, \mathrm{Ca}$ : $68 \pm 21 \%, \mathrm{I}: 61 \pm 6 \%, \mathrm{P}: 67 \pm 19 \%, \mathrm{Mg}: 77 \pm 22 \%$. Fe, I and $\mathrm{P}$ were extracted more easily by digestion fluid than by water at the same $\mathrm{pH}$, but $\mathrm{Ca}$ and $\mathrm{Mg}$ were extracted to the same extent.
\end{abstract}

(Received June 3, 1987)

海に囲むれているわが国では，海藻は昔から重要な食 糧資源である。近年，その食品としての価値が再評価さ れて, 海藻に含まれる多糖類など各種成分の含有量 ${ }^{122}$ が 測定され化学的に検討されている。

無機成分についても，種類ならびに含有量が非常に多 いことから，無機質給源としての栄養的価値を評価する ために多くの研究3) カ7がされてきた。しかし，海藻の無 機成分の消化吸収についての研究(例 ${ }^{839)}$ は非常に少ない。 無機成分は結合形態により消化吸収に差が生じることが 予想される。また，ワカメのヨウ菜の消化吸収に関する 人体実験では、ヨウ素の消化吸収率はワカメの摂取量に より異なることが報告されている。

$\overline{\mathbf{T} 770}$ 徳島市蔵本町三丁目 18
本研究は, ワカメの部位ならびに加工法の違いが無機 成分の溶出に与える影響を調べることを目的とし，各試 料を人工消化液に浸漬振㬈し, 溶出する無機成分 $(\mathrm{Fe}$, $\mathrm{Ca} ， \mathrm{I}, \mathrm{P}, \mathrm{Mg}$ ) の量を測定した。また，ヨウ素につい ては有機溶媒別溶出量も測定したので報告する。

\section{実 験方 法}

1. 試料

ワカメ (Undaria pinnatifida) の概略図は Fig. 1 の ような模式図で表わされる。各部位からの試料の処理は 下記のように行った。

素干し：1984年 5 月に，鳴門市大毛島において収穫さ れた天然ワカメ（20 株）を海水洗浄し，部位別225) に分 け, 風乾後温風乾燥し $\left(40^{\circ} \mathrm{C}\right)$, 幅約 $5 \mathrm{~mm}$, 長さ約 $3 \mathrm{~cm}$ 
Table 1. Contents of nutritive element in "Naruto Wakame".

(Sampling date : 1984, 5, 16a,b) 1985, 5c).

\begin{tabular}{lccrrrr}
\hline \hline Sample parts & Size & Moisture dry (\%) & Ash (\%) & Protein (\%) & Lipid (\%) & $\begin{array}{c}\text { Carbohydrate } \\
(\%)\end{array}$ \\
\hline $\begin{array}{c}\text { Suboshi } \\
\text { Sporophylla) }\end{array}$ & Small & $8.16 \pm 1.3$ & $26.2 \pm 2.7$ & $14.9 \pm 1.8$ & $5.0 \pm 3.6$ & 46 \\
& Large & $8.36 \pm 2.9$ & $26.1 \pm 2.5$ & $14.9 \pm 1.6$ & $6.8 \pm 0.9$ & 43 \\
& Stipe & $8.27 \pm 0.4$ & $43.9 \pm 0.1$ & $7.5 \pm 0.1$ & $1.5 \pm 0.1$ & 39 \\
& Rhizoid & $8.48 \pm 0.6$ & $41.1 \pm 0.1$ & $12.4 \pm 0.1$ & $1.4 \pm 0.1$ & 37 \\
Suboshi \\
$\quad$ Leaf
\end{tabular}

a,b) Naruto Ōge-island "natural Wakame sporophyll". c) Naruto Ōge-island "cultured Wakame". Mean $\pm \operatorname{SD}(n=4)$. The values are calculated on dry basis.

に細く切る。溶媒でョウ素を抽出する場合にのみさらに Mullen 粉碎機にかけ 60 mesh の微粉末とした。各試料 別によく混合して試料瓶に入れ $-20^{\circ} \mathrm{C}$ に保存した。

生ワカメ：1986年 2 月に徳島市で市販していた朝取れ 鳴門ワカメ葉部を, 幅約 $1 \mathrm{~cm}$, 長さ約 $5 \mathrm{~cm}$ に切って ただちに実験に供した。

灰干ワカメ：1985年 5 月産の灰干し洗い采ワカ人を, 幅約 $5 \mathrm{~mm}$ ，長さ約 $3 \mathrm{~cm}$ に切り陚料瓶に入れ $-20^{\circ} \mathrm{C}$ に保存し試料とした。

\section{2. ヨウ素の溶媒別抽出法}

Fig. 2 にワカメヨウ素の溶媒別抽出過程を示した。ま ず $40^{\circ} \mathrm{C}$ の蒸留水で, 次にェタノール, ベンゼンの順 (い 才゙れも $20^{\circ} \mathrm{C}$ 前後) に, 抽出溶媒 $100 \mathrm{ml}$ に粉末試料 2 $\mathrm{g}$ を一昼夜浸漬後, スターラーで摚拌 ( 5 時間) 抽出し, $20,000 \mathrm{~g}$ で 10 分間遠心分㕍した。この操作は 3 回反復 した。どの抽出液にもョウ素が認められないことを確認 した。この抽出液をニッケル・ルッボに集め, 水抽出物 は $100^{\circ} \mathrm{C}$, 他はドラフト中 $40^{\circ} \mathrm{C}$ で溶媒除去し, その後 アルカリ溶融してヨウ素定量の試料とした。

\section{3. 人工消化液調整法}

日本薬局方の崩壊試験法の人工消化液調整法 ${ }^{10}$ に上る 人工胃液 $[0.2 \% \mathrm{NaCl}, 9.6 \times 10$ unit-pepsin, $0.063 \mathrm{M}$ $\mathrm{HCl}(\mathrm{pH} 1.2)]$ および人工腸液 $[0.1 \%$ pancreatin in Tris-buffer (pH 7.5)] を用いた。

\section{4. 人工消化実験}

Fig. 3 に示す過程で人工消化実験を行った。

\section{5. 無機犋定量用試料溶液の調整法}

磁性ルツボでは鉄等の焼き込みの危険性があるので分 解ビンを用いた。試料ワカメおよび人工消化液抽出物を 凍結乾燥した試料をこの分解瓶に入れ，王水を加えて白

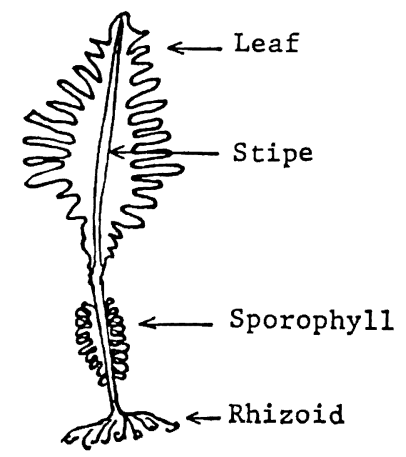

Fig. 1. Wakame (Undaria pinnatifida).

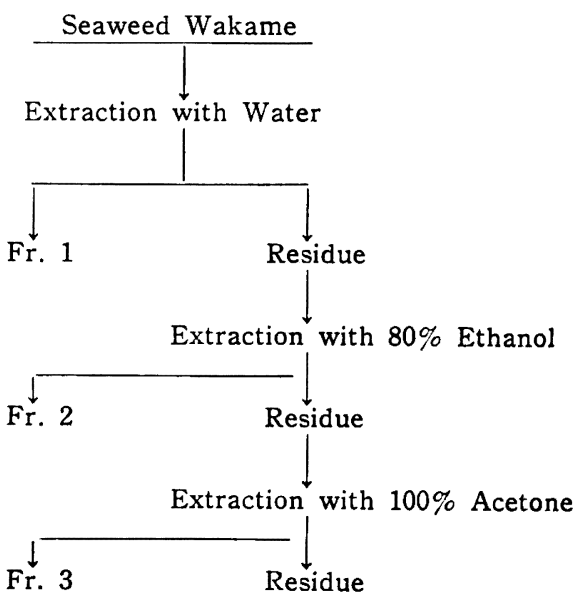

Fig. 2. Procedure of fractionation of iodine in wakame.

色になるまで湿性灰化し， $1 \mathrm{~N}$ 塩酸で定溶し分析に供し た。 


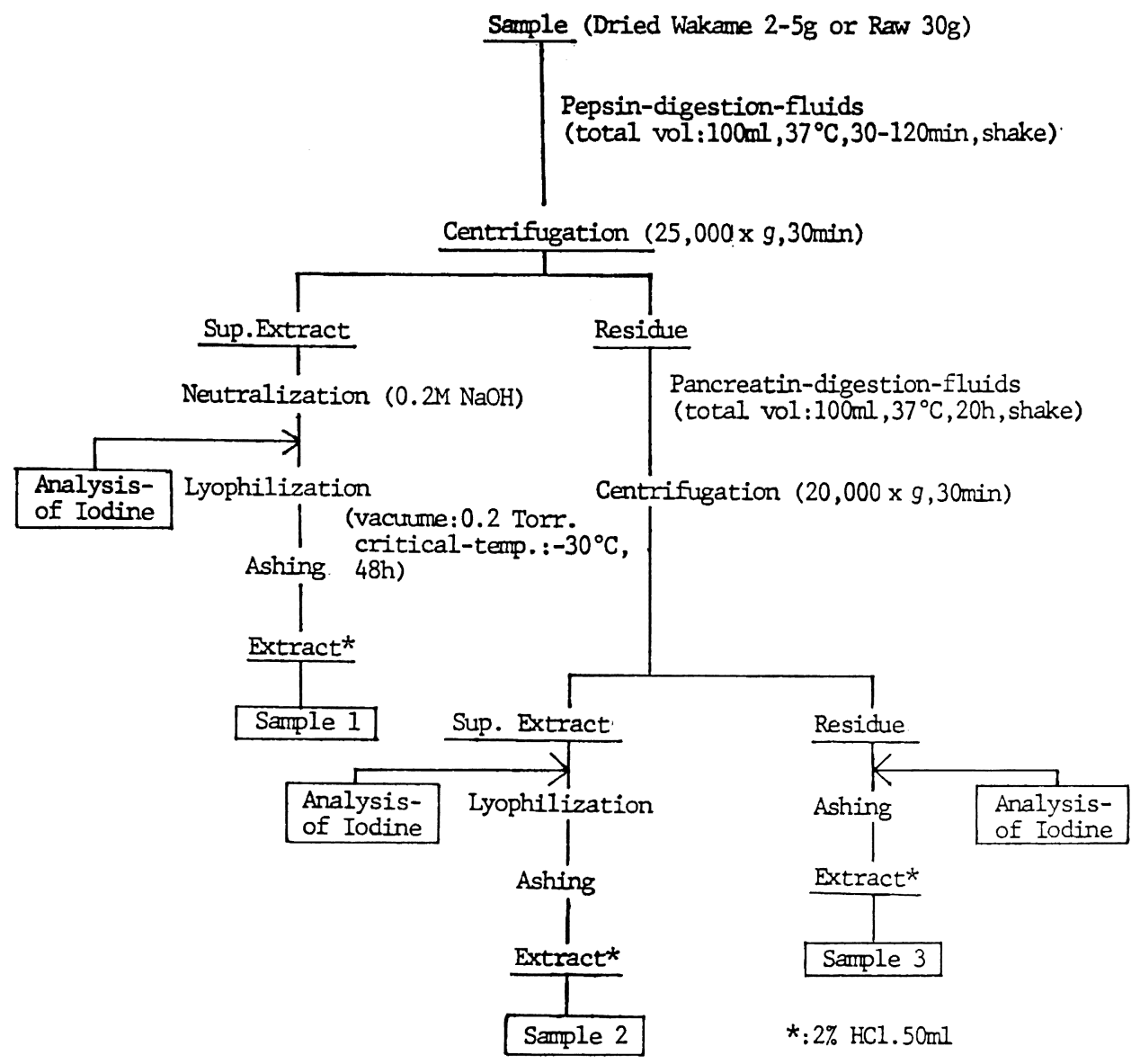

Fig. 3. Preparation procedure of minerals sample from seaweed-wakame during immersion treatment with artificial digestion fluids.

\section{6. 定贯法}

1）水分の定量：海藻類の乾燥法である常圧加熱乾燥 法11に従って測定した。

2）粗灰分の定量 ${ }^{11)}$ : 磁製ルッボを用い, $550^{\circ} \mathrm{C}$ の電 気炬で灰化し測定した。

3）タンパク質の定量：ミクロケールダール法11炕よ り定量した。

4）鉄の定量：のーフェナントロリン比色法11飞より 定量した。

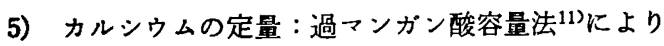
測定した。

6）リン定量：パナドモリブデン酸比色法"11により測 定した。

7） ヨウ素の定量：フルカリ溶融後 Larsen の方法 ${ }^{12}$ により測定した。

8） マクネシウムの定量 : Magnesium B-Test Wako （キシリジルブルー法）により測定した。

\section{実騃結果および考察}

\section{1. 試料ワカメの一般成分}

試料ワカメの部位別粗灰分, 粗タンパク質, 粗脂肪含 有量の無水換算値を Table 1 に示した。粗灰分は成実葉 部の莁と根に含有量が多く，粗タンパク質は灰干し系ワ カメと素干しワカメに多い，粗脂肪は成実葉部にとくに 多く含まれていた。

\section{2. 試料ワカメの無機成分含有量}

Table 2 は試料ワカメの部位別無機質含有量の無水換 算値である。鉄は成実葉部の根および素干し葉部に含有 量が多く，カルシウムは成実葉部の茎と根および灰千し 釆ワカメに含有量が多い。リン含有量に有意差はない。 ヨウ素は成実葉部大の含有量が同部位小より少ないのは 前報り と同じ。グネシウムは成実葉部の含有量が灰干 し, 素干し, 生ワカメと比較して有意に少ない。

\section{3. ワカメのヨウ素の溶媒別溶出量}

Table 3 Kワカメのヨウ素の溶媒別溶出量を示した。 
Table 2. Contents of minerals in "Naruto Wakame". (Sampling date : 1984, 5, 16a,b,c) 1985, 5d) 1986, 2()).

\begin{tabular}{|c|c|c|c|c|c|c|}
\hline Sample parts & Size & $\mathrm{Fe}(\mathrm{mg} \%)$ & $\mathrm{Ca}$ (mg \%) & $\mathrm{P}(\mathrm{mg} \%)$ & I (ppm) & $\mathrm{Mg}$ (mg \%) \\
\hline \multicolumn{7}{|l|}{ Suboshi } \\
\hline \multirow[t]{4}{*}{ Sporophylla) } & Small & $8.7 \pm 0.5$ & $647 \pm 56$ & $321 \pm 17$ & $139 \pm 51$ & $266 \pm 37$ \\
\hline & Large & $8.5 \pm 2.7$ & $845 \pm 12$ & $322 \pm 19$ & $95 \pm 27$ & $163 \pm 25$ \\
\hline & Stipe & $6.3 \pm 2.8$ & $1,458 \pm 25$ & $237 \pm 17$ & $110 \pm 42$ & $300 \pm 37$ \\
\hline & Rhizoid & $30.0 \pm 5.1$ & $1,176 \pm 30$ & $425 \pm 25$ & $157 \pm 46$ & $312 \pm 36$ \\
\hline \multicolumn{7}{|l|}{ Suboshi } \\
\hline Leaf ${ }^{b}$ ) & & $21.4 \pm 3.1$ & $920 \pm 80$ & $415 \pm 55$ & $233 \pm 32$ & $765 \pm 48$ \\
\hline Stipe ${ }^{\text {) }}$ & & $9.7 \pm 1.1$ & $749 \pm 79$ & $229 \pm 32$ & $110 \pm 9$ & $542 \pm 26$ \\
\hline \multicolumn{7}{|l|}{ Haiboshi } \\
\hline Washed-Itov & $e^{d)}$ & $11.8 \pm 2.7$ & $1,670 \pm 88$ & $505 \pm 60$ & $142 \pm 27$ & $821 \pm 55$ \\
\hline Raw-Wakam & & $7.7 \pm 0.5$ & $496 \pm 96$ & $386 \pm 54$ & $178 \pm 32$ & $759 \pm 57$ \\
\hline \multicolumn{7}{|c|}{$\begin{array}{l}\text { a,b,c) Naruto Ōge-island "natural Wakame". d) Naruto Ōge-island "cultured Wakame". e) Commercial } \\
\text { raw Wakame. } \\
\text { Mean } \pm \mathrm{SD}(n=4) \text {. The values are calculated on dry basis. }\end{array}$} \\
\hline \multirow{2}{*}{\multicolumn{2}{|c|}{ Sample }} & \multicolumn{5}{|c|}{ Solvents } \\
\hline & & Water & Ethanol & Benzene & Residue & Total \\
\hline \multicolumn{7}{|c|}{ Suboshi-Wakamea) } \\
\hline \multirow[t]{2}{*}{ Whole } & & $58 \pm 23$ & $25 \pm 19$ & 0 & $126 \pm 44$ & $213 \pm 16$ \\
\hline & & $(28 \%)$ & $(12 \%)$ & 0 & $(59 \%)$ & $(100 \%)$ \\
\hline \multicolumn{7}{|l|}{ Suboshi } \\
\hline \multirow{2}{*}{\multicolumn{2}{|c|}{ Sporophylla)-large }} & $36 \pm 9$ & $13 \pm 10$ & 0 & $66 \pm 26$ & $115 \pm 31$ \\
\hline & & $(31 \%)$ & $(11 \%)$ & 0 & $(57 \%)$ & $(100 \%)$ \\
\hline
\end{tabular}

a) Naruto Ōge-island "natural Wakame".

Mean $\pm \mathrm{SD}(n=7) .(\%)=$ Rates of extraction.

ワカメのヨウ素は残査に多いことから，上記有機溶媒不 溶の高分子結合態ヨウ素がいちばん多いと考えられる。 後藤 ${ }^{13}$ は昆布のヨウ素の形態について，放射性同位元素 を用いた実験で，市販たし昆布のヨウ素の約 $90 \%$ は， 無機態ヨウ素であると述べている。また，奥田と江頭14) は海藻のヨウ素はほとんど有機態で, いろいろな食用海 藻の水溶の抽出物がチ才硫酸ナトリウム滴定で無機ヨウ 素反応を示さないこと，アルカリ溶融か灼熱した後にヨ ウ素反応を呈すことを報している。目黒,小笠原ら ${ }^{15) る ， ~}$ チオ硫酸ナトリウム滴定が抽出ヨウ素の定量に適当でな いときには，イオン交換樹脂によって有機物を除去すれ ば滴定できると報じ，海藻ヨウ素の結合形態には疑問点 が多い。本実験でもワカメを完全にアルカリ溶融して後 に初めてヨウ素反応を呈したことからワカメのヨウ素の
形態はおもに有機態であろらと考える。

\section{4. ワカメの人工消化実験}

ワカメについて人工消化実験を行い，溶出する無機質 の経時的変化を Fig. 4 に示した。

人工消化液処理により，粗灰分は総量の約 $70 \sim 86 \%$, 鉄は 14 98\%，カルシウムは 41 90\%，ヨウ素は約 51 〜65\%, リンは 44 90\%, マグネシウムは 52 98\% の 溶出が認められた。すなわち、ワカメに存在する無機質 はワカメの部位と加工法により人工消化液への溶出率が 異なりまた無機質の種類によっても溶出傾向に差を生

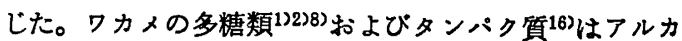
リ可溶のものが多く、これらと結合している無機質は腸 液で処理した場合に溶出すると思われた。 


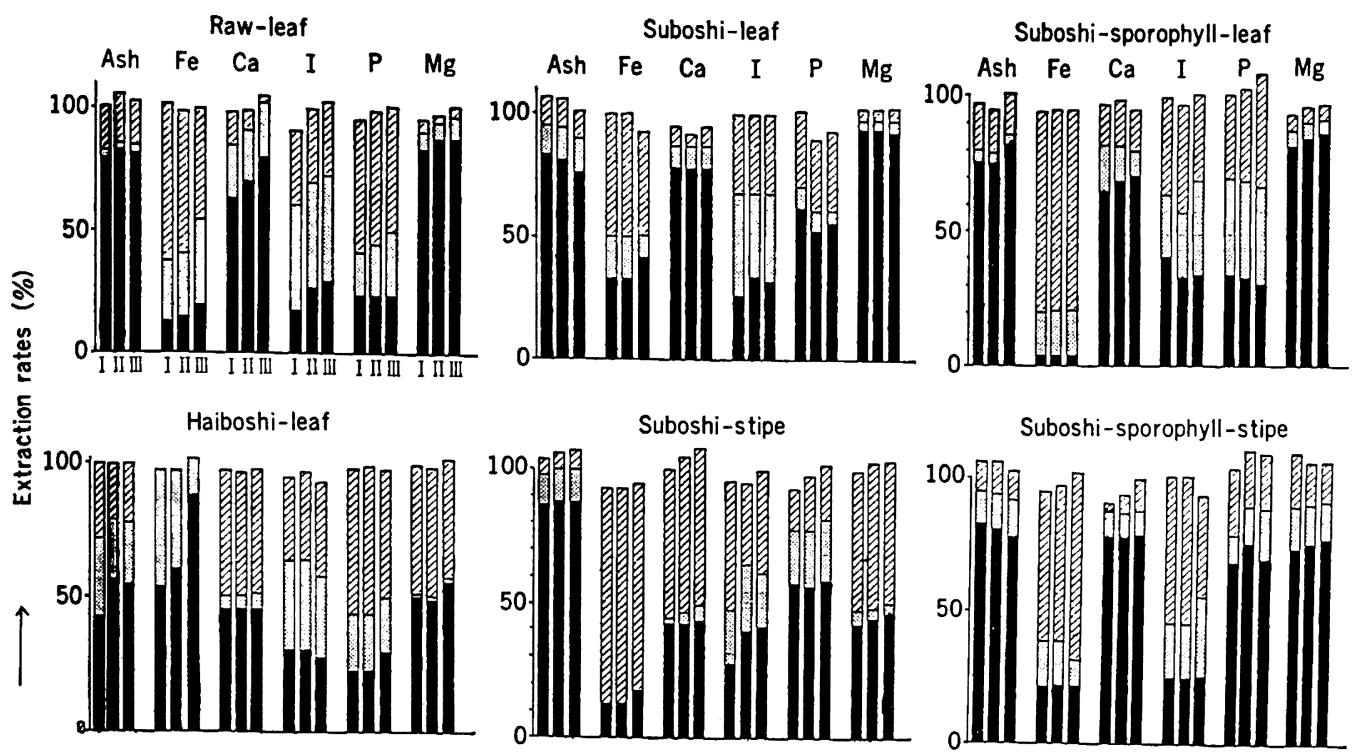

Fig. 4. The rates of minerals extracted from various "Naruto Wakame" (dried wakame $5 \mathrm{~g}$ or raw 30 g) during successive immersion treatment : first, into pepsin for $30 \mathrm{~min}$ ( I ), $60 \mathrm{~min}$ (II) and $120 \mathrm{~min}$ (III) ; second, into Pancreatine for $20 \mathrm{~h}$, both using $100 \mathrm{ml}$ of fluides at $37^{\circ} \mathrm{C}$ by 60 times shaking per min.

Pepsin, 0 Pancreatine, $\mathbb{Z}$ Residue.

\section{5. 生ワカメの無機復の各種漫出液による溶出}

Fig.4 の溶出差が消化酵素によるのか，あるいは溶媒

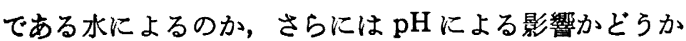
を調へるために，生ワカメを用いて実験し Fig. 5 に示 す結果を得た。鉄, ヨウ素, リンは pepsin-pancreatin 処理で溶出量が高くなる (Fig.5-B， C， E)。カルシウ ム, マグネシゥムの溶出は消化酵素の種類よりも $\mathrm{pH} の$ 影響を強く受け，とくに酸性（pH 1.2）での溶出が大で あった (Fig. 5-B, C)。

6. 人工消化液によるワカメ無機成分の常用量中（乾 燥 $: 5 \mathrm{~g}$, 生: $30 \mathrm{~g}$ ）の可溶化量

上記消化実験によるワカメ無機成分の可溶化量は乾燥 品 $5 \mathrm{~g}$ （生は $30 \mathrm{~g}$ ）を食した場合の平均値は，粗灰分 1 g. 鉄 $0.6 \mathrm{mg}$ ，カルンウム $32 \mathrm{mg}$ 、リン $13 \mathrm{mg} 、$ ヨウ 素 $40 \mu \mathrm{g}$ ， マグネシウム $25 \mathrm{mg}$ であった。汁の実, 酢 の物などの従来の調理法にとらわれず，多量に食するこ とができれば，無機質の種類と量のバランスのとれた良 好な食品であると思われる。とくにヨウ素に関しては， 成人 $100 \mu \mathrm{g} / \mathrm{day}^{17)}$ 必要といわれるが，非常に良い給源 となりらると考える。

\section{要}

約

1）試料ワカメの一般栄養成分は，粗灰分 $16 \sim 44 \%$, タンパク質 $7.5 \sim 24.2 \%$, 粗脂肪 $1.4 \sim 6.8 \%$, 炭水化物 37 49\%，であった。無機成分含有量は，ワカメの大き
さ,ならびに部位により差があり, 試料ワカメ $100 \mathrm{~g}$ 当 たり, 鉄 $6.3 \sim 30 \mathrm{mg}$ ，カルシウム $647 \sim 1,176 \mathrm{mg}$ ，ヨ ウ素 95 157 ppm，リン 273〜 425 mg， マグネシウム 163 312 mg であった。

2）ワカメに存在するョウ素の溶媒別溶出量は, 温水 可溶 $28 \sim 31 \%$, エタノール可溶 $11 \sim 12 \%$, ベンゼン可 容 $0 \%$ ，上記溶媒不溶 57 59\% であった。

3） ワカメ無機成分の人工消化液による溶出量を測定 した結果, いずれも初期 30 分の溶出が大で，さらに時 間の経過とともに溶出が增し，120 分では部位ならびに 加工法により差はあるが，粗灰分 $85 \pm 10 \% ，$ 鉄 $45 \pm 29$ $\%$ ，カルシウム $68 \pm 21 \% ，$ ヨウ素 $61 \pm 6 \%$ ，リン $67 \pm$ 19\%，マグネシウム $77 \pm 22 \%$ の溶出が認められた。

4）これらの溶出が消化䣼素によるのか，たんに溶媒 によるのか調べるために，生ワカメを試料とし，消化酵 素を含まない液にも浸漬振逿して溶出を調べた結果, 鉄, ヨウ素, リンは, 消化酵素により容出量が增加した。カ ルシウム，マグネシゥムについては消化酵素の影響は認 められす酸性液での溶出が大であった。

終わりに本研究に用いたワカメの提供をしていただい た徳島県食品加工試験場水畜産科長 渡边忠美博士に 深 謝します。この研究は日本栄盖・食糧学会第 18 回中四 国大会ならびに第 40 回総会で発表したものである。 

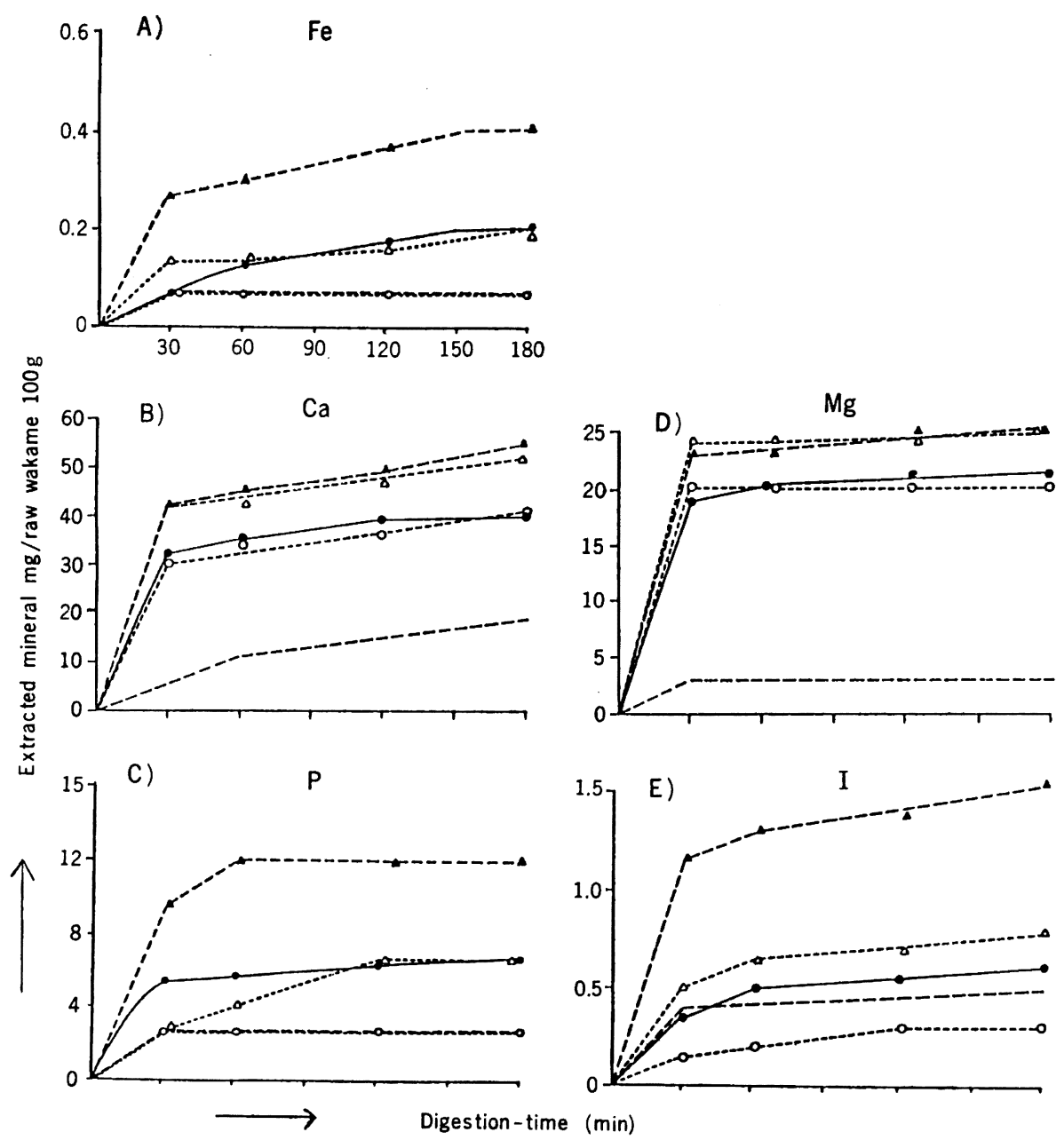

Fig. 5. Amounts of extracted minerals during immersion treatment for $30-180 \mathrm{~min}$ from $30 \mathrm{~g}$ "raw Wakame" into various fluids of $100 \mathrm{ml}$ at $37^{\circ} \mathrm{C}$ by 60 times shaking per min.

-..- Water, $\bigcirc-.-\bigcirc$ dil. $\mathrm{HCl}(\mathrm{pH} \mathrm{1.2)}, \bullet-\bullet$ Pepsin, $\triangle \cdots \Delta$ dil. $\mathrm{HCl}$ followed by tris-buffer (pH 7.5), ^... $\Delta$ Pepsin followed by pancreatine.

\section{文献}

1) 日本水産学会 (編): 海藻の生化学々利用（水産学 シリーズ 45), 9-131 (1983), 佰星社厚生閣(東京)

2) 伊藤里美: 家政学研究, 33 (1)，6 (1986)

3) 今井明美, 小泉英夫, 堤 忠一: 食総研報 (Rept. Natl. Food Res. Inst.), 37, 163 (1980)

4) 沢田節男, 蟻井緑郎, 田原 功, 吉田節郎, 小黒 美樹：四国公衛誌，31 (1)，16 (1986)

5）伊藤里美, 三好 保, 藤井正信, 今木雅英 : 栄食 誌, 40, 205 (1987)

6) 関本邦敏, 星野信行, 戸塚耕二, 渡部 昭, 山下 光雄 : 栄食誌, 36, 21 (1983)

7) 関本邦敏, 遠藤昭夫, 片峯伸一郎 : 栄食誌, 39 , 67 (1986)

8) 田中ミチコ, 森 宏枝, 石澤敬子 : 東京家政学院 紀要, 23, 45 (1983)

9) 山田勇樹, 三好 保, 今木雅英, 吉村 武：日衛 誌, 41, 817 (1986)
10）日本公定書協会：日本薬局法，第一部解説書，B206 (1971)，廣川書店（東京）

11）日本食品工業学会, 食品分析法編集委員会 (編)： 食品分析法, 83, 241，102，282，269，360，413， (1983)，光琳（東京）

12) Larsen, B. : Handbook of Phycological Methode (Hellebust, J.A. and Craigie, J.S., eds.), 185 (1978), Cambrige Univ. Press (London)

13）後藤たへ：栄羔と食糧, 19，248（1966）

14) Okuda, Y. and Eto, T. : J. Coll. Agric. Univ. Tokyo, 5, 342 (1916)

15) Meguro, H., Abe, T., Ogasawara, T. and Tuzimura, K. : Agric. Biol. Chem., 31, 999 (1967)

16）新崎輝子，美野典子：栄養と食糧, 26, 129 (1973)

17）厚生省保健医療局健康增進栄養課 (編)：日本人の 栄養所要量, 89 (1985), 第一出版 (東京)

(1987 年6月 3 日受理) 